\title{
Antifungal activity of red galangal oil (Alpinia purpurata K. SCHUM) against Malassezia furfur
}

\author{
Hernandi Sujono ${ }^{1}$, Senadi Budiman ${ }^{1}$, Yusi Fudiesta ${ }^{1}$, Ahmad Sahroni ${ }^{1}$, Jasmansyah $^{1, *}$, Lela Lailatul \\ Khumaisah $^{2}$ \\ ${ }^{1}$ Department of Chemistry, Faculty of Sciences and Informatics, Universitas Jenderal Achmad Yani, \\ J1. Terusan Jenderal Sudirman, Cimahi, 40531 \\ ${ }^{2}$ Study Program of Chemistry, Faculty of Science and Technology, Muhammadiyah University of Sukabumi, Jl. \\ R. Syamsudin, No. 50, Sukabumi, 43313 \\ *E-mail: jasmansyah@unjani.ac.id
}

DOI: https://doi.org/10.26874/jkk.v2i2.40

Received: 12 Nov 2019, Revised: 25 Nov 2019, Accepted: 26 Nov 2019, Online: 30 Nov 2019

\begin{abstract}
Plant red galangal (Alpinia purpurata K. Schum) is one of the many spices used as bio-pharmacy products which contain essential oil that is active as an antifungal and antibacterial agent. Isolation of volatile oil from red galangal rhizome (Alpinia purpurata K. Schum) uses the method of water and steam distillation so as to get the rendemen $0.1062 \%$, the density $0.9524 \mathrm{~g} / \mathrm{mL}$ and the index of refraction by 1.4862. Results from GC-MS (Gas Chromatography-Mass Spectrometry) retrieved 30 compounds contained in red galangal rhizome oil with 10 major compounds i.e. 1,8-cineole (40.92\%), acetyl chavicol $(10.33 \%)$, cis $\beta$-farnesene (6.91\%), 1-caryophillene (6.32\%), 1- $\beta$-bisabolene $(3.37 \%), \beta$ elemene (3.23\%), $\alpha$-pinene (3.20\%), $\beta$-sesquiphellandrene (2.32\%), $\beta$-pinene $(2.21 \%)$, and germacrene$\mathrm{D}(1.90 \%)$. The inhibition test was done by agar diffusion method and different variations of concentration $(1,2,3$ and $4 \%$ ) compared with ketoconazole $2 \%$ as positive controls and dimethyl sulfoxide (DMSO) as negative controls with an incubation period of 2x24 hours. The test results show that the essential oil of red galangal rhizome (Alpinia purpurata K. Schum) can inhibit the growth of the fungus Malassezia furfur with the inhibitory power on concentrations1, 2, 3 and $4 \%$ were $7.15 \mathrm{~mm}$, $13.87 \mathrm{~mm}, 16.05 \mathrm{~mm}$ and $20.05 \mathrm{~mm}$, respectively. As for comparison, ketoconazole $2 \%$ was used as positive (+) control that produces inhibitory zone $27.20 \mathrm{~mm}$ and dimethyl sulfoxide (DMSO) as negative control (-) which does not produce inhibitory zones.
\end{abstract}

Keywords: Essential oil, red galangal rhizome (Alpinia purpurata K. Schum), Malassezia furfur

\section{Introduction}

The Indonesian region has a tropical climate with high rainfall intensities and very rich in natural resources that are useful in daily life. Besides being a food and building material, Indonesia's abundant natural resources are also widely used as traditional medicine. The researchers conduct studies on native Indonesian plants that can be used as medicines for pharmaceuticals and industry. One of the plants with potencies was red galangal (Alpinia galanga K. Schum) [1].

Red galangal (Alpinia purpurata K. Schum) is one type of spice that is widely used as a phytopharmaca product. Red galangal rhizome contains volatile oil which is active as an antifungal and antibacterial. The red galangal rhizome contains green colored essential oil $\pm 1 \%$ [2].

Since ancient times, galangal is often used as a fungus such as Pitiriasis versicolor. In the community, galangal is used to remove white spots like tinea versicolor on the skin by applying galangal pieces to the affected part of the body. The content of galangal in the form of essential oils and chemical compounds methyl khavikol acetate is efficacious as an antifungal [3]. Some references mention, essential oils from red galangal rhizome (Alpinia purpurata $\mathrm{K}$. Schum) are mostly $\beta$-pinene, 1,8-cineole, $\alpha$-pinene [4], 
$48 \%$ methylinamat, $20-30 \%$ 1,8-cineole, $1 \%$ camphor, and the rest d-pinen, galangin, and eugenol as causes of spiciness in galangal [5].

The study of ethanol extract of red galangal rhizome which applied as an antibacterial, gave antibacterial activity to mice infected with the bacterium of Klebsiella pneumoniae sputum bronchitis patients in vivo. By giving different doses, the higher the dosage given, the greater antibacterial activity of ethanol extract of red galangal rhizome (Alpinia purpurata $\mathrm{K}$. Schum), i.e. with dose I $(0.756 \mathrm{~g} / 200 \mathrm{~g} \mathrm{BW}$ rat $)$ of $3.07 \%$, $2 \mathrm{x}$ dose I (1.512 g/200 g BW rat) of $15.05 \%, 4 \mathrm{x}$ dose I (3,024 g/200 g BW rat) of $19.20 \%$ [6].

Research on the bioactivity of essential oils of red galangal rhizome (Alpinia purpurata $\mathrm{K}$. Schum) on the growth of Bacillus aereus and Pseudomonas aeruginosa proved that at a $20 \%$ concentration of essential oils from red galangal rhizome could inhibit the activity of both bacteries with inhibition zone diameter was $17.6 \mathrm{~mm}$. The compounds used as antibacterial are cineol, similiaritas, and dodekatriena. Then, more intensive research found that white galangal essential oil (Alpinia galanga) with dimethyl sulfoxide (DMSO) solvent in vitro with agar diffusion method using Sabouraud Dextrose Agar (SDA) media and incubated for 48 hours, the effectiveness of the Candida albicans at $1.56 \%$ concentration and able to kill the fungus at $3.25 \%$ concentration [7].

For the validity of the study, a study was conducted on the red galangal rhizome (Alpinia purpurata K. Schum) essential oil against the growth of Malassezia furfur.

\section{Material and Methods}

\subsection{Extraction of Red Galangal Rhizome Oil}

$8 \mathrm{~kg}$ of fresh red galangal (Alpinia purpurata

K.Schum) is cleaned and then distilled by steamair distillation method for 8 hours. The essential oil obtained from distilling are added by anhydrous $\mathrm{Na}_{2} \mathrm{SO}_{4}$ to dehydrate it from water.

\subsection{Making the Red Galangal Rhizome Essential Oil Concentration Variation}

The essential oil of red galangal rhizome are obtained from the distillation of air vapor and diluted using dimethyl sulfoxide (DMSO) with 4 variations of concentration (1, 2, 3 and 4\%).

\subsection{Making the McFarland Standard Solusiton 0.5}

$99.5 \mathrm{~mL} 0.18 \mathrm{H}_{2} \mathrm{SO}_{4}$ is added to a $100 \mathrm{~mL}$ volumetric flask, then added $0.5 \mathrm{~mL} \mathrm{BaCl}_{2} 0.048$
$\mathrm{M}$, shaked until homogeneous and has the McFarland 0.5 standard turbidity.

\subsection{Preparation of Test Suspension}

Malassezia furfur colonies were taken one ose, and then puted into $5 \mathrm{~mL} 0.9 \% \mathrm{NaCl}$ and shaked until homogeneous to meet the McFarland 0.5 standard turbidity.

\subsection{Inhibition Test of Essential Oils of Red Galangal Rhizome Against Malassezia furfur}

This inhibitory test aims to learn about the essential red galangal rhizome oil in inhibiting the growth of Malassezia furfur. This test was carried out using the agar diffusion method by heating the Sabouraund Dextrose Agar (SDA) medium until it melted and poured $25 \mathrm{~mL}$ in a petri dish. Leave it to harden and putted in autoclaf for 24 hours. Malassezia furfur suspension was added to SDA media by applying it using sterile cotton bud. In SDA media, a pit is made using the tip of the tube test. In each wellbore drops of red galangal oil with a concentration of $1,2,3$ and $4 \%$. DMSO was used as a negative control and ketoconazole $2 \%$ as a positive control. After that, it was incubated at $37^{\circ} \mathrm{C}$ for $2 \times 24$ hours.

The essential oil of red galangal rhizome will diffuse into the test media and produce a clear zone around it. Clear zones obtained by using the calipers with the following calculation formula:

$$
\frac{d_{1}+d_{2}}{2}-x
$$

Where $d_{1}$ is diameter of clear vertical media zone, $\mathrm{d}_{2}$ is diameter of clear horizontal media zone, and $\mathrm{x}$ is diameter of well hole $(7 \mathrm{~mm})$.

The large clear zone is produced proportional to the inhibitory power produced by the active substance containing the red galangal rhizome oil $[7,8]$.

\section{Results and Discussion}

\subsection{Water-Steam Distillation of Red Galangal Rhizome}

The red galangal rhizome (Alpinia purpurata K. Schum) used in this study was obtained from the Paketingan, Bojongsari Village, Kedungwaringin District, Bekasi Regency, West Java. This area is in the lowlands with an average temperature of $28-30{ }^{\circ} \mathrm{C}$. The red galangal 
rhizome sample used in fresh condition is as much as $8 \mathrm{~kg}$ then distilled by the water-steam distillation method. In water-steam distillation method, the processed material is placed on a perforated barrier. The distilled kettle is filled with water until the surface of the water is not far from the bottom of the filter. Steam from the water flows into a pile of plant tissue and the essential oil is distilled together with steam from water. After condensing, the essential oils will form a separate layer of water which can then be collected. The water-steam distillation process of $8 \mathrm{~kg}$ of red galangal rhizome produces $8.5 \mathrm{~mL}$ of essential oil that yield $0.10625 \%$.

Characteristics of essential oils from red galangal rhizomes produce $0.9524 \mathrm{~g} / \mathrm{mL}$ density and refractive index of 1.4862. Based on the literature, the yield of red galangal rhizome essential oil is $\pm 1 \% 2$. Variations in the yield of essential oils produced are thought to be caused by genotypes or varieties, harvest age, fertilization, growing environment, fresh or dry rhizomes, distillation methods or extraction methods and the type of solvent used [9].

\subsection{GC-MS Analysis}

The GC-MS analysis of essential oil from red galangal rhizome carried out in the Chemical Instrumentation Laboratory of the Islamic University of Indonesia were 30 components (Figure 1). The 10 main components can be seen in Table 1. The compounds contained in the red galangal essential oil sample were in accordance with previous studies conducted by Zoghbi et al., In 1999 with the largest major components including $\beta$-pinene, 1,8 -cineol and $\alpha$-pinene [4].

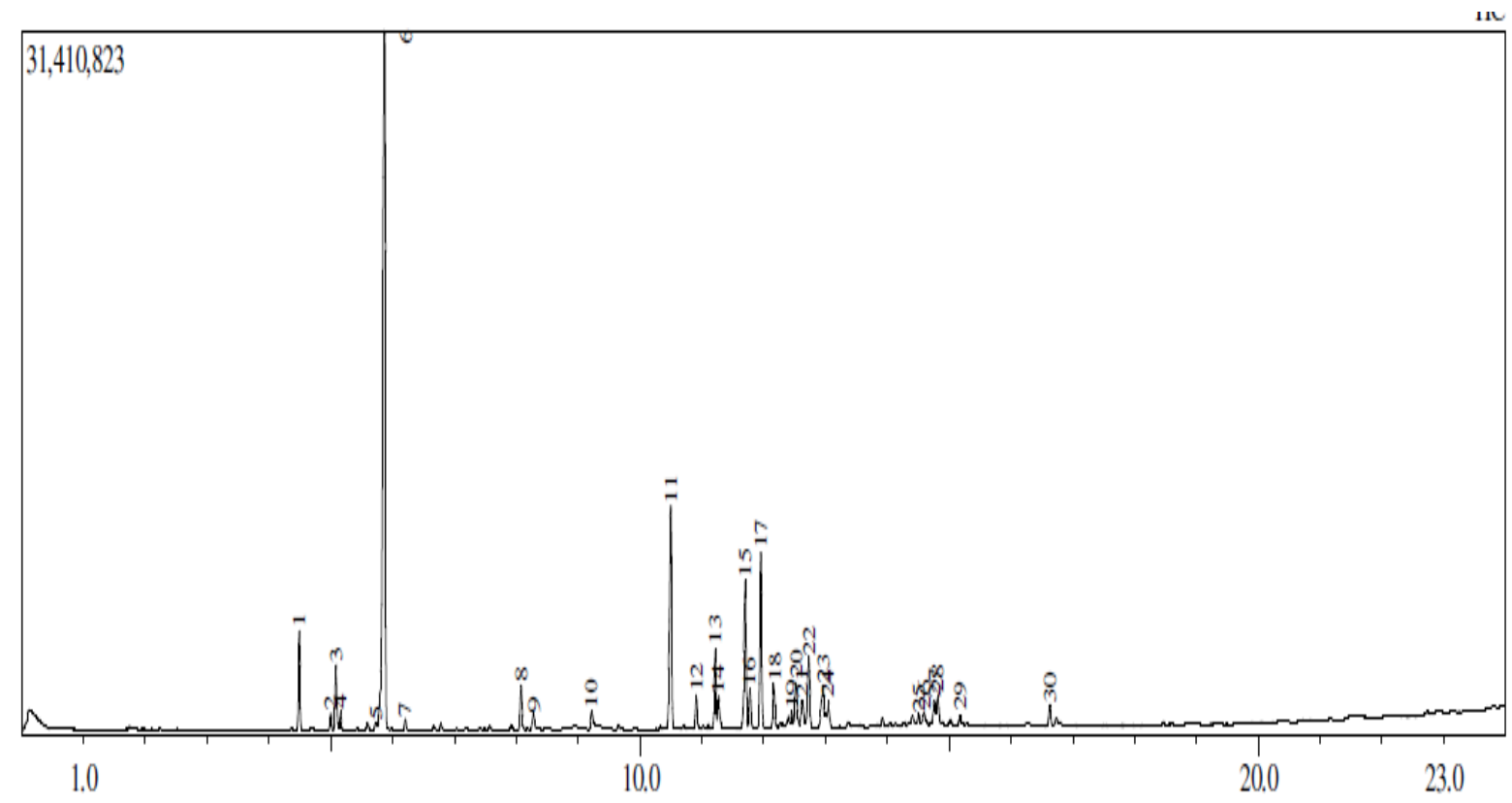

Figure 1. Chromatogram of essential oil from red galangal rhizome

Table 1. Main Components of Red Galangal Essential Oil

\begin{tabular}{clcc}
\hline No. & \multicolumn{1}{c}{ Compound } & \% Peak Area & Peak No. \\
\hline 1 & 1,8-cineol & 40.92 & 6 \\
2 & Cavikol acetate & 1033 & 11 \\
3 & cis $\beta$-farnesene & 6.91 & 17 \\
4 & 1-caryophillene & 6.32 & 15 \\
5 & 1- $\beta$-bisabolene & 3.37 & 22 \\
6 & $\beta$-elemene & 3.23 & 13 \\
7 & $\alpha$-pinene & 3.20 & 1 \\
8 & $\beta$-sesquiphellandrene & 2.32 & 23 \\
9 & $\beta$-pinene & 2.21 & 3 \\
10 & germacrene-D & 1.90 & 20 \\
\hline
\end{tabular}




\subsection{Antifungal Activity}

The inhibitory test results of red galangal rhizome essential oils (Alpinia purpurata K. Schum) on the growth of Malassezia furfur showed the presence of inhibitory zones formed in all variations of concentration. In Figures 2 and 3, it can be seen that the essential oil of red galangal rhizome can inhibit the growth of Malassezia furfur with concentrations $1,2,3$ and $4 \%$ which are characterized by the formation of inhibition zones around the essential oil region. Barrier zones are also formed in addition of ketoconazole with concentration $2 \%$. However, addition of dimethyl sulfoxide (DMSO) did not show any inhibition zone formation after 48 hours of incubation.

The measurement of inhibition zone of Red galangal rhizome essential oils (Alpinia purpurata K. Schum) on the growth of Malassezia furfur after 48 hours incubation can be seen in Table 2 .

In Table 2 it is shown that the average inhibition zone of red galangal essential oil against the growth of Malassezia furfur on various concentrations $(1,2,3$ and $4 \%$ ) are $37.15 \mathrm{~mm}$, $13.87 \mathrm{~mm}, 16.05 \mathrm{~mm}$, and $20.65 \mathrm{~mm}$ respectively. Ketoconazol with a concentration of $2 \%$ as a positive control (+) resulted in a inhibition zone of $27.20 \mathrm{~mm}$ and dimethyl sulfoxide (DMSO) as a negative control (-) with no inhibitory zone.

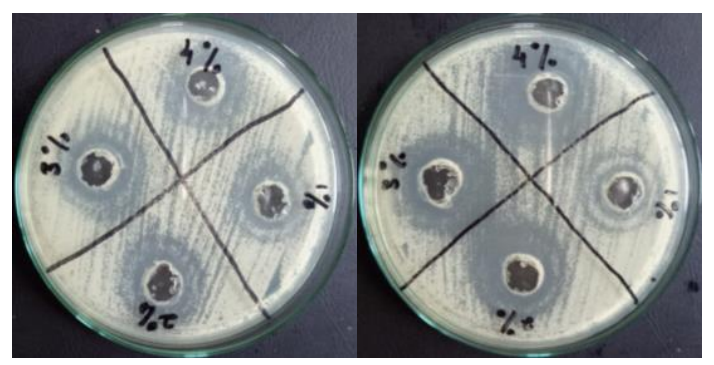

Figure 2. The inhibitory test of red galangal rhizome essential oil (Alpinia purpurata K. Schum) on Malassezia furfur with various concentrations in two repetition

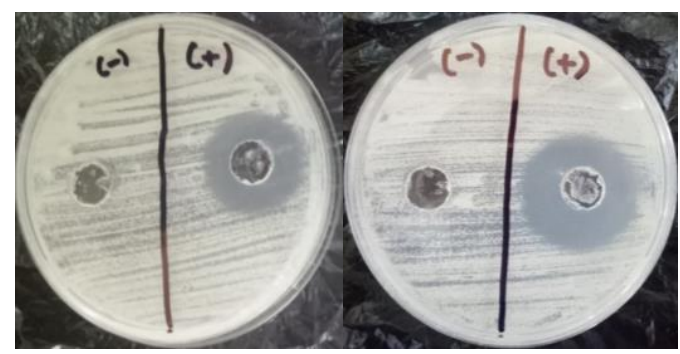

Figure 3: Inhibitory test of $2 \%$ ketoconazole as a positive (+) control and dimethyl sulfoxide (DMSO) as a negative (-) control

Table 2. The inhibition zones of red galangal essential oil (Alpinia purpurata K. Schum) on Malassezia furfur

\begin{tabular}{ccccccc}
\hline \multirow{2}{*}{ Repitition } & \multicolumn{7}{c}{$\begin{array}{c}\text { Diameter of Inhibition Zone (mm) in Various } \\
\text { Concentrations and Control }\end{array}$} \\
\cline { 2 - 7 } & $1 \%$ & $2 \%$ & $3 \%$ & $4 \%$ & $\mathrm{C}(+)$ & $\mathrm{C} \mathrm{(-)}$ \\
\hline I & 7.50 & 14.40 & 16.20 & 21.50 & 29.20 & 0 \\
II & 6.80 & 13.30 & 15.90 & 18.60 & 26.20 & 0 \\
\hline Average & 7.15 & 13.87 & 16.05 & 20.65 & 27.20 & 0 \\
\hline
\end{tabular}

The results obtained showed that the essential oils of red galangal rhizome (Alpinia purpurata $\mathrm{K}$. Schum) were able to inhibit the growth of Malassezia furfur by increasing the diameter of the inhibitory zone. There is a difference in the diameter of the inhibitory zone in each, because each concentration is different. The greater the concentration then the greater the component of substances contained in it so that the inhibitory zone formed is also different. The greater the effect of the extract, the greater the effect it will cause [7].

Inhibition zones of red galangal oil (Alpinia purpurata $\mathrm{K}$. Schum) at a concentration $1 \%$ can be categorized into moderate barriers because the inhibitory zone generated was in range 5-10 $\mathrm{mm}$. at concentrations 2 and $3 \%$ can be categorized into strong barriers because the inhibitory zone generated was $10-19 \mathrm{~mm}$. Whereas $4 \%$ can be categorized into very strong barriers due to the inhibitory zone was $>20 \mathrm{~mm}$. Antifungal strength is classified into 4 . If the inhibitory diameter is 5 $\mathrm{mm}$ or less, the inhibiting activity is categorized as weak. $5-10 \mathrm{~mm}$ inhibition zone is categorized as medium, the inhibition zones of 10-19 $\mathrm{mm}$ are categorized as strong and the inhibition zone of 20 $\mathrm{mm}$ or more is categorized as very strong [7].

In this study, it was not focused on compounds that play a major role in inhibiting the growth of Malassezia furfur. However, it can be 
seen from the activity of each compound of the red galangal rhizome oil. According to Efruan, et al. (2016), 1,8-cineol have fresh characteristics and aroma of camphor and spicy taste that have bioactivity that has many benefits, namely a decrease in locomotor (anticonvulsant) activity, anticancer, antitumor, antibacterial, antifungal, anti-inflammatory, antioxidant, insecticides and can reduce the risk of cardiovascular disease [10]. Sinaga E. stated that the content of galangal oils and chemical compounds of methyl khavikol acetate efficacious as an antifungal but there has been no further research to mention the working mechanism of essential oils and chemical compounds of methyl khavikol acetate as antifungal [3].

In this research, test of red galangal rhizome (Alpinia purpurata K. Schum) oil activity compared with $2 \%$ ketoconazole as $(+)$ control and dimethyl sulfoxide (DMSO) as a (-) control. Ketoconazole is one of the azole class antimicotics which is often used in the treatment of pitiriasis versicolor (tinea versicolor). The treatment of pitiriasis versicolor (tinea versicolor) is by inhibiting the synthesis of ergosterol and disrupting the integrity of the membrane of fungal cells [11]. DMSO is used as an essential oil solvent so that it can be dispersed evenly throughout the medium to obtain homogeneous results. The results showed that the inhibition zone of salicylic acid was greater than red galangal rhizome oil (Alpinia purpurata K. Schum), whereas DMSO does not provide fungal inhibition or killing activities. This is indicated by the absence of inhibition zone on Malassezia furfur.

\section{Conclusion}

Based on the results of the study it can be concluded that steam-distillation can be used as a way to get red galangal rhizome oil (Alpinia purpurata K. Schum). The yield of red galangal rhizome oil (Alpinia purpurata K. Skhum) obtained was $0.10625 \%$. Red galangal rhizome oil (Alpinia purpurata K. Schum) consists of 10 of the largest compounds, namely; 1.8-sineol (40.92\%). kavikol acetate $(10.33 \%)$. cis $\beta$-farnesen $(6.91 \%)$. 1-karyophilene (6.32\%). 1- $\beta$-bisabolen $(3.37 \%)$. $\beta$-element (3.23\%). $\alpha$-pinen $(3.20 \%) . \quad \beta$ seskuifelandren (2.32\%). $\beta$-pinen $(2.21 \%)$. germacren-D (1.90\%). The inhibition of red galangal rhizome oil (Alpinia purpurata K. Schum) on the growth of Malassezia furfur fungus with $1 \%$ red galangal rhizome oil concentration of $7.15 \mathrm{~mm} .2 \%$ red galangal rhizome oil concentration of $13.87 \mathrm{~mm} .3 \%$ red galangal rhizome oil concentration of $16.05 \mathrm{~mm}$ and $4 \%$ red galangal rhizome oil concentration of $20.05 \mathrm{~mm}$.

\section{References}

[1] Muhlisah. F., 1999, Тети-temuan dan Emponempon Budaya dan Manfaatnya.Penerbit Kanisius: Yogyakarta

[2] Azzahra, F.A., Utami, R., Nurhartadi, E., 2013, Pengaruh Penambahan Minyak Atsiri Lengkuas Merah (Alpinia Purpurata) pada Edible Coating terhadap Stabilitas $\mathrm{pH}$ dan Warna Fillet Ikan Patin Selama Penyimpanan Suhu Beku. Jurnal Teknosains Pangan Vol 2 No 4.

[3] Sinaga, E., 2000, Alpinia galangal (L.) Willd. Di dalam www.warintek.apiji.or.id/artikel/ttg_tanam an_obat/unas.

[4] Zoghbi. M.D.G.B., Andrade, E.H.A., and Maia, J.G.S., 1999, Volatile constituents from leaves and flowers of Alpinia speciosa K. Schum.. and A. purpurata (Viell.) Schum. Flavour Fragr. J. 14. 411-414.

[5] Darwis . S.N., Indo, M., dan Hasiyah, S., 1991, Tumbuhan Obat Famili Zingiberaceae, Pusat Penelitian dan Pengembangan TanamanIndustri, Bogor.

[6] Kandou, L.A., 2016, Uji Aktivitas Antibakteri Ekstrak Etanol Rimpang Lengkuas Merah (Alpinia Purpurata (Vieill) K. Schum) Terhadap Bakteri Klebsiella Pneumoniae Isolat Sputum Penderita Bronkitis Secara In Vivo, Jurnal Ilmiah Farmasi - Unsrat, 5 (3), 131-137.

[7] Andayani, A., Susilowati, A., and Pangastuti, A., 2014, Anti Candida Minyak Atsiri Lengkuas Putih (Alpinia galanga) terhadap Candida Albicans Penyebab Candidiasis Secara In-Vitro, EL-VIVO, 2 (2), 1-9.

[8] Surjowardojo, P., Susilorini, T.E., and Benarivo, V., 2016, Daya Hambat Dekok Kulit Apel Malang (Malus sylvertris Mill) Terhadap Pertumbuhan Escherchia coli dan Streptococcus agalactiae Penyebab Mastitis Pada Sapi Perah. J. Ternak Tropika. 17 (1), 11-21.

[9] Rialita. T.. Rahayu. W.P.. Nuraida. L. and Nurtama. B., 2015, Aktivitas Antimikroba Minyak Esensial Jahe Merah (Zingiber officinale var. Rubrum) dan Lengkuas Merah (Alpinia purpurata K. Schum) 
terhadap Bakteri Patogen dan Perusak Pangan. Agritech. 35 (1).

[10] Efruan, G.K., Martosupono, M., and Rondonuwu, F.S., Review: Bioaktifitas Senyawa 1,8-Sineol pada Minyak Atsiri, Prosiding Seminar Nasional Pendidikan dan Saintek 2016, 171-181
[11] Widyawaty, 2006, Uji banding efektivitas laos (Alpinia galanga) 2\% dengan ketoconazol $2 \%$ terhadap pertumbuhan Malassezia furfur pada pitiriasis versicolor secara in vitro, Thesis, Diponegoro University. 